\title{
Civilizing the Other: Beauty, Intimate Labor, and Affective Encounters in Berlin's Brazilian Waxing Studios*
}

\author{
Maria Lidola**
}

\begin{abstract}
Over the past 15 years, waxing (hair removal) studios have emerged in central Berlin and grown rapidly in number. Specializing in the "Brazilian method," this beauty salon sector has increasingly been occupied by Brazilian migrants. In addition to being a simple hair removal service, I argue that the intimate work carried out in these salons encompasses an educational and even civilizing effort from the point of view of Brazilian depiladoras. The intimacy of their work allows for affective encounters in which Brazilian women are not seen merely as service providers. They embody the specialist in a form of beauty and femininity that is desired by German clients. Appropriating these rare moments of intimacy, Brazilian depiladoras act as educators not only for a more hygienic and more feminine corporeality but also for a more humanized sociality with the "other." Based on long-term ethnographic research in Berlin, I discuss both the agency of beauty work and its limits within the coloniality of feminized and ethnicized labor.
\end{abstract}

Keywords: Brazilian Migration, Beauty, Body Care, Intimate Labor, Intersectionality.

\footnotetext{
* Received on 08 November 2020, accepted on 03 November 2021.

** Division of Social and Cultural Anthropology, Department of History and Sociology, University of Konstanz, Konstanz, Baden-Württemberg, Germany. maria.lidola@uni-konstanz.de / https://orcid.org/0000-0002-8761-2573
} 
Civilizando as outras: Beleza, trabalho íntimo e encontros affectivos em Brazilian Waxing Studios em Berlim

\section{Resumo}

Nos últimos 15 anos, waxing studios (estúdios de depilação) surgiram no centro de Berlim e cresceram rapidamente em número. Especializados no "método brasileiro", esses salóes de beleza constituem um setor de trabalho cada vez mais ocupado por migrantes brasileiras. Neste artigo, argumento que mais do que um serviço de remoção de pelos, o trabalho realizado nos salões possui dimensão educativa e civilizadora do ponto de vista das depiladoras brasileiras. A intimidade do trabalho possibilita encontros afetivos nos quais as brasileiras não são categorizadas como prestadores de serviço. Antes, passam a personificar a figura de especialista em um padrão de beleza desejado pelas clientes alemãs. Apropriando-se desses momentos de rara intimidade com as "outras", mulheres da sociedade dominante, as depiladoras atuam como educadoras não só para uma corporalidade considerada mais higiênica e mais feminina, senão também para uma sociabilidade humanizado com o "outro". Baseado em uma etnografia de longo prazo, discuto tanto os espaços de agência nesses relacionamentos temporários e frágeis dentro do ambiente de um trabalho altamente hierarquizado e estigmatizado quanto seus limites.

Palauras-chave: Migração brasileira, Beleza, Cuidado corporal, Trabalho intimo, Interseccionalidades. 
Introduction

"Brazilian depiladoras are considered the silver bullet of waxing, using honey wax to create bare facts." This statement in the June 2009 issue of the German edition of the lifestyle magazine Cosmopolitan commented, like other magazines, on the booming business of this special depilation technique newly introduced in beauty salons throughout major German cities. In particular, "waxing studios," which concentrate solely on this type of cosmetic offer, shot up like mushrooms in Berlin's central districts from 2006 onwards and shaped this business branch in a special way: The majority of studios are not only run by Brazilian women, but the advertisement of their services is also carried out via cultural branding as "Brazilian." The reference to (stereotypical images of) Brazil can be found in studio names (Bella Brasil, Amazon Waxing, Rio Waxing, Copacabana Brazilian Waxing Studio, Brasil Wax Studio, etc.); in the name of the service itself ("Brazilian waxing," which in Germany refers to the depilation technique, not to intimate hair removal as in the United States); the names of the service providers (using the Portuguese word depiladora); or the design of the façades, interiors, studio homepages, and advertising flyers (showing elements of beach and holiday motifs as well as images of tropical plants and birds, the Sugar Loaf Mountain, Christo Redentor, and so on). They may also show naked, hairless body parts (legs, abdomen) of seemingly white women. Conspicuously visible to every passerby, the depilation of a variety of different parts of the body is offered here, from the armpits to the genital area.

In the same year, a study report on intimate body modifications was published (Borkenhagen; Brähler, 2010) and widely discussed by the national press. Hannes Caspar-Petzold-a journalist working for Germany's largest leftist newspaper, taz-commented on this in the online edition published on July 14, 2009, with the weasel words "Germany at the very bottom," pointing especially to the $80 \%$ of women between the ages of 18 and 30 who affirmed that they depilated. The reasons for depilation given included their "own ideal of beauty" and that "role models also depilate," but Caspar-Petzold also blamed the porn industry and sexualization in everyday life for this development. In the readers' comments that followed, there was great indignation in response to the journalist's one-sided interpretation. Readers criticized the politicization of individual preferences in private life and emphasized their freedom to modify their bodies. The reader forums of other major newspapers and magazines, which had also reviewed the study, were similarly controversial. By summer 2009 at the latest, body hair removal-especially in the pubic area-had become not only a routine practice, especially among young people, but also a matter of polarization.

What has taken center stage in heated debates about beauty norms and "pornization" (Cokal, 2007), on the one hand, and personal freedom of corporal practices, on the other, was in turn widely welcomed as an overdue change in German personal hygiene and corporeality by Brazilians working in the waxing business. Furthermore, the rapid rise of waxing studios was proudly described by the Brazilian community in Germany as the entrepreneurial success and social recognition of Brazilian migrant women. Waxing studios had become places of intimate labor and affective encounters which transcended a mere modulating work on other women's bodies (who were mostly affluent, and of German national origin). As I will show in this paper, these studios also turned into places of care, where Brazilian depiladoras considered their work a humanizing and even civilizing mission not only with regard to other women's bodies but also in terms of sociality.

This statement is at first glance highly problematic and contradicts established feminist views on beauty, corporeality, and women's (caring) labor. For decades, feminist voices have warned that the beauty myth and related bodily practices are effective instruments for transforming the female body into a gendered, disciplined body, which is considered an integral part of women's oppression (Wolf, 1991). In particular, the norm of a hairless body turns symbolically into a guarantor of gender difference and inequality (Basow, 1991; Basow; Braman, 1998; Peixoto Labre, 2002; Toerien; Willkinson, 2003; Tiggemann; Lewis, 2004). Furthermore, turning from the site of body images and disciplining practices to the site of labor, waxing studios have joined the list of feminized work areas in the urban service industry. Parallel to other caring labor segments, the beauty service sector has become more and more ethnicized but also culturally branded in recent decades (other examples include "Thai massage studios" and "Asian nail salons"; see Sunanta, 2020; Kang, 2010). Like other forms of intimate labor, their service work targets clients who belong to the majority society, 
for whom the cultural branding is equated with the specialized expertise of the service giver at the same time that the feminized and ethnicized work force provides a source for exploitation (Boris; Parreñas 2010). Moreover, as with other forms of bodily intensive caring labor, service providers generally suffer from devaluation in terms of earning opportunities, professional mobility, and social status, which are often combined with bad working conditions and other evils attendant of neoliberal flexibilization and the coloniality of labor (Gutiérrez Rodríguez, 2010). Even more, conceived as a form of affective relation and economic transaction, waxing enters the debate on the incommensurateness of money and intimacy in caring labors (Zelizer, 2005; Boris; Parreñas 2010; Piscitelli, 2016).

Despite considering these invaluable contributions of feminist scholarship as important heuristic devices, this paper adopts a different stance. I will try to trace the perceptions and interpretations of those Brazilian women who entered and appropriated the waxing business shortly after its introduction into the Berlin beauty service sector and who provided me with a different reading of their services and of their understandings of beauty, body care, and corporeality. I am aware that their statements and conceptions may also be problematic and must be interpreted in the context and moment of my research and, moreover, that they should be reflected against the intersecting power structures of the coloniality of (feminized) labor to which the waxing business is subject. Nonetheless, I opted to take on the challenges inherent to a feminist ethnography (Davis; Craven, 2016), which not only listens to and respects the divergent perspectives of my interlocutors but takes them as the very basis of mutual knowledge production.

Departing from these insights, I will engage with waxing as a form of body care and intimate labor that is shaped by intersecting power structures of gender, class, race and nationality of the two postcolonial contexts, Brazil and Germany. Tracing the social embeddedness of this transaction of money and intimacy, I will show that the transnational setting holds divergent meanings of social positionalities that materialize in the performativity of encounters, that is in face to face-even skin to skin-meetings (Ahmed, 2000), in the waxing cabin between German client and Brazilian depiladora. I argue that this divergence and the intimacy of interaction provide Brazilian migrant women with agency. These affective encounters may even destabilize dominant power relations and provide a space for a decolonial approach to sociality.

I had the opportunity to witness the formation of the waxing business in Berlin from its very beginning in 2006 while researching the feminization of Brazilian migration in Germany. Initially, my interests focused on the emergence of small-scale businesses run by Brazilian women, the majority of whom had formerly worked within the broad category of care work since their arrival in Berlin. However, in the course of intensive ethnographic research between 2010 and 2013, my interlocutors advised me to focus more heavily on the sensitive, bodily, and intimate dimensions of their service. ${ }^{1}$ Before discussing the body work and intimate encounters in Brazilian waxing studios in depth, I will give some theoretical and contextual remarks on the entanglements of beauty, body care, and the construction of otherness and alterity from a transnational and postcolonial perspective.

\section{Beautiful modern: Intersecting beauty and sensing body work}

Since its introduction into the German urban beauty service sector in 2006, the success of waxing became most visible in the steadily increasing numbers of so-called waxing studios that emerged in Germany's major cities, especially Berlin. There, a German businesswoman and her Austrian associate inaugurated the first studio, Wax in the City, in 2005, having become acquainted with the honey-wax method in Brazilian beauty salons during a visit to Rio de Janeiro. Back in Berlin, the two women decided to set up their own waxing business, with one of their first steps

\footnotetext{
1 I began my qualitative research in 2009 and worked closely with 15 Brazilian waxing studio owners. Besides participant observation, the empirical material is based on life history interviews and semi-structured topic-centered interviews. Additional interviews were conducted with other Brazilian waxing studio owners; employees of predominantly Brazilian but also Polish, Turkish, Lebanese, and German national backgrounds; clients of mainly German nationality; and other migrant entrepreneurs in the Berlin beauty sector.
} 
being to recruit experienced depiladoras from Rio de Janeiro to come to Berlin. The business proved successful within a very short time. Consequently, the two entrepreneurs developed an inhouse training program for Brazilian women who were already living in Berlin but had no experience in cosmetic work. Some of these women, having finished their training and worked as depiladoras at Wax in the City, decided to leave the salon to pursue their own waxing businesses. Shortly after, a "second generation" of waxing businesswomen emerged who noticed the other salons' success. Some had already worked in the beauty business in Brazil before migrating to Germany, while others specifically sought training as depiladoras during longer stays in Brazil or in one of Berlin's emerging waxing studios. Since then, Brazilian migrant women have contributed considerably to the branding of waxing as Brazilian. They have also claimed their share of the change in beauty ideals, body care, and corporeality in Germany, but that has been so heavily criticized by feminist voices. In the following, I will briefly present feminist and anthropological approaches to beauty and corporeality, paying special attention to the postcolonial Brazilian context.

Although hair removal (including in the pubic zone) constitutes body work that can be traced far back in history throughout multiple cultural contexts worldwide, its increased commercialization, especially in the Global North, has been treated as a recent phenomenon resulting from modernity that has been explained by gendered and sexualized beauty ideals in the context of the increased exposure of the (almost naked) body in the media and its echo in everyday life (Cokal, 2007). Hair removal would present the tip of the iceberg of a range of body practices and beauty norms imposed primarily on women in order to maintain women's oppression, at least symbolically, "at a time"-as Merran Toerien and Sue Wilkinson state- "when other gender markers were being challenged" (Toerien; Wilkinson, 2003:340). Explanatory approaches like this one were popularized, especially by Naomi Wolf. In her much-cited book The Beauty Myth (1991), she states that beauty ideals and related cosmetic practices are effective instruments for transforming the female body into a gendered, disciplined body and therefore constitute late modernity's primary source for the oppression and objectification of women.

Since then, feminist voices have increasingly challenged this monolithic perspective on body work and beauty practices in multiple ways (see Colebrook, 2006). While criticizing this one-sided approach to beauty as equally hegemonic, they have called for the acknowledgment of the diversity and complexities of women's experiences. This encompasses, on the one hand, questioning the underlying binary categorization of male-female (and along these lines: oppressors-suppressed) by including other intersecting axes of difference and oppression. Beverley Skeggs had argued already in 1997 that beauty practices always involve class-related work of demarcation and belonging (but also efforts at their dissimulation), where femininity is normatively defined from a privileged class position (Skeggs, 1997). Along with class, race has become a further decisive analytic category for understanding beauty norms and body practices (Craig, 2002). Thus, following an intersectional approach to beauty and body modifications, scholars have increasingly dismissed the idea of a generality of beauty norms and values by looking instead at the different ways that "beauty matters" (Brand, 2000) within and along intersecting regimes of difference. Scholars have also shown, how beauty practices, operating within the coloniality of power, have provided spaces for agency exactly through the logic of differánce in the iterability of performative acts (e.g. Vartabedian, 2016) Furthermore, the "practices and meanings of beauty are embedded in everyday life, as well as the circumstances that have given rise to particular beauty cultures historically" (Liebelt, 2016:10; see also Lidola, 2015). This includes also how understandings of beauty and body care practices among women are shaped by local social institutions and places where they interact on a daily basis, such as beauty salons, fitness studios, and the like (Kang, 2010).

How social and racialized hierarchies affect and complicate beauty ideals and body care becomes particularly clear in postcolonial nations like Brazil. Since colonialism, beauty norms have coincided with a white, European ideal, however inaccessible and non-representational it is for the greater part of the population. Through perpetuating and normalizing white beauty ideals, the persistent social inequalities derived from Brazil's colonial heritage are inscribed into people's bodies and are perceptible in countless situations in everyday life (Machado-Borges, 2009; Jarrín, 2017), despite decades of officially affirming a "triumphant mestiçagem" [miscegenation] for the nation 
(Edmonds, 2007). To this day, and despite having been largely deconstructed by science and social movements, the underlying myth of democracia racial constitutes powerful discourses and embodied practices that do not challenge whiteness as a social norm (Nascimento, 2007). However, it also allows for a broad spectrum of situational positionalities, ranging from quase branco ("almost white") to quase preto ("almost black"). Again, it is the body through which a manipulation of racialized and intersecting social attributions also becomes possible to a certain degree and opens up a certain possibility of passing. ${ }^{2}$ Due to the malleability of the body in its aparência, racialized and class-related beauty practices enable a certain degree of agency, especially for women who historically and currently belong to social groups that are otherwise granted few resources (Adelman; Ruggi, 2007; Edmonds, 2010). Thus, the body as a "symbol which consecrates and makes visible differences among social groups" (Goldenberg, 2010:236) is at the same time understood as one of the few accessible capitals through which these differences can be manipulated and is therefore perceived as a fundamental vehicle for social ascension (Goldenberg, 2010; Edmonds, 2010). Accordingly, manufacturing the bodily appearance to a certain degree through cosmetic practices simultaneously challenges Brazil's intersecting and thoroughly gendered race and class hierarchy while simultaneously confirming that hierarchy through its performativity.

Acknowledging the diversity of women's experiences has also meant, on the other hand, directing attention to the feelings, perceptions, and senses related to beauty and body work that arise from the complexity of individual experiences and which transcend and exceed beauty as defined by discourse. That is, beauty matters not only in terms of the bodies and subjects that the beauty discourse produces but also in terms of how people emotionally incorporate and embody beauty (Jarrín, 2017) and how they perceive, sense, and feel beauty through visual impressions as well as through touching, smelling, and feeling body, skin, and hair. Perceptions of beauty arise from but also "trigger individual memories, emotions, and other embodied experiences" (Jarrín, 2017:12).

However, this affective dimension is not neutral, but also subject to the historicity of epistemic power. As postcolonial scholars have widely shown, beauty as an affective practice of body care and body modification has been especially exploited in modern-colonial politics of hygiene and sanitation, as Maria Del Priore also states for the Brazilian (post)colonial context (Del Priore, 2000). Anne McClintock argues more general that cleanliness, obtained through body care and industrialized cosmetic products, became signified as a "poetics of social discipline" in modernist discourse, where not just the individual-or rather feminine-body was freed from its natural wilderness, purified from contamination and subjected to the idea of domestication (McClintock 1995:32). As part of the colonial enterprise, the domesticated body demarcated a boundary between people and communities, and served as a symbolic analogy and legitimation of the civilizing mission, that is the domestication of the undomesticated other (McClintock, 1995). Body care as domestic hygiene was thus turned into a powerful instrument of the colonial regime of differentiation. As epistemic power, hygiene thereby also eradicates other meanings and affective histories of body care, cleanliness and not least beauty. Such decolonial meanings of body care can be found for example in the Amerindian context of Brazil, where body care rather constituted social bonding, and where body modification meant the embodiment of a sociality-of-with-ness in the humane world (e.g. Viveiros de Castro, 1998).

However, in the modern-colonial enterprise, hygiene became not just an affective instrument of powerful differentiation in the name of civilization, but also constituted, in Sara Ahmed's words, an affective economy of the desired and the abject (Ahmed, 2000), of what is felt to be a clean and a beautiful body in regard to others, but also to the self (cf. Jarrín, 2017). Since Brazil's colonial past, conceptions and politics of hygiene have been an integral part of the coloniality of othering, eugenic debates, and racial politics in Brazil's nation-building and closely tied to the project of modernity

\footnotetext{
2 These include straightening curly hair and avoiding the sun as well as more permanent measures, such as the surgical procedures that are also spreading among the working classes (such as a nose operation popularly known as "correction"; see Edmonds, 2010; Jarrín, 2017). However, it also comprises most common body care practices, such as manicures, the extensive use of perfumes and lotions, and makeup, which not least supposes a certain consumption potential related to the upper classes.
} 
(Sant'Anna, 2005). The heterogeneous composition of Brazil's population was initially seen as an obstacle to this, as it deviated from the European (i.e., white) ideal, which coincided with "modern" in the racist dispositif of the time. The discourse of democracia racial and of a nação mestiça from the 1930s onwards therefore also implied a positive revaluation of the postcolonial nation in relation to Europe. Likewise, it highlighted the "tropical" peculiarity wherein the concern for body care surpassed the exigencies of the hygienic modern of the time (Freyre, 1987; cf. Edmonds, 2010, critical on this). The historian Denise Bernuzzi de Sant'Anna summarized Brazil's historical national and international efforts to become and be recognized as a modern nation in this respect: "especially iln Brazil, beauty does not only describe a certain fashionable physiognomy, to the detriment of an appearance that is from now on considered outdated and therefore ugly. It also always refers to certain nuances of that old dream that has long haunted the elites of this country, namely to be modern and civilized" (Sant'Anna, 2005:122, my translation). ${ }^{3}$

Hygiene discourses fueled the popularizing cosmetic industry. In Brazil, a growing range of hygiene products were made accessible across classes since the 1960s (Sant'Anna, 2011), even though the body advertised in the media was a socially classified and racialized one oriented towards a white ideal. The cosmetics and advertisement industry aimed especially at the sensory dimension of beauty in order to exploit the consumption potential especially of women. From the 1960s onwards, body care was not only described as a hygienic necessity for a modern nation but advertised as an individual debt owed to oneself, with cosmetic products also accessible to the lower classes (Sant'Anna, 2005). Body care was increasingly understood as an individual, self-determined effort rather than as the effect of collective pressure and was even associated with empowerment and emancipation in light of the second women's movement of the time. Advertised as prazer a si mesma (Sant'Anna, 2005:133ff; Andrade, 2003) and having psychological implications, these practices were now localized on the emotional level and used once more synonymously with terms like cleanliness, orderliness, and care, but always in reference to the female body (Andrade, 2003). Smooth, hairless skin obtained by depilation can be seen as the epitome of the embodiment of the hygiene dispositive of that time: cleanliness is immediately perceived, not only visibly but especially haptically, even olfactorily. Unpleasant body fluids such as sweat and urine (as much as their odors), which had been identified as a potential source of disease in the hygiene discourse of the early 20th century, could get stuck in body hair. Like these liquids and odors, body hair was also considered as unclean, as matter out of place, as dirt, and emotionally signified with disgust. Depilation, in turn, strengthened its significance as "major testimony of hygiene and seduction" (Sant'Anna, 2011:305).

As shown, beauty is as much a sensory experience as it is a regime of social norms to be iteratively performed (cf. Jarrín, 2017). Body care and beauty practices are thus not to be understood one-sidedly as aligning practices in relation to an ideal: gendered, classified and racialized. Instead, they must also be examined in their affective dimensions yet contextualized within historically produced, socially configured, and culturally located power relations (Gutierrez Rodríguez, 2010; Ahmed, 2004). The framing of beauty in the realm of personal hygiene, as an emotional favor to oneself, and as embodied conditionality for belonging to the modern nation beyond racial and social categorizations has been perpetuated, albeit with variations, to this day (Andrade, 2003; Sant'Anna, 1995). As a sensory experience, however, beauty is momentary and thus only made durable through the infinite work of permanent repetition (Sant'Anna, 1995). The significance of body care and beauty practices must therefore be understood in light of its ambiguity of not only producing the corporeality of modernity but also its constant efforts to dissimulate embodied colonial difference. As such, performing beauty through body work and cosmetic practices can either normalize and reassert or modify and decenter norms and discourses (Jarrín, 2017). The remainder of this paper combines an intersectional approach to beauty and body care with a focus on the affective and sensuous dimension, which decenters dominant perspectives on beauty that position women as mere objects or, on the contrary, highlight women's agency and

${ }^{3}$ Orig.: "no Brasil, em particular, o gesto que embeleza não desenha somente uma fisionomia mais à moda, em detrimento de uma aparência doravante considerada ultrapassada, portanto, feia. Ao fazê-lo, ele também revela as diversas nuanças do antigo sonho de ser moderno e civilizado, que há muito persegue as elites desse país" (Sant'Anna, 2005:122). 
disembodied subjectivity. Following Claire Colebrook's suggestion, I approach the question of beauty not from a moral but from a pragmatic stance (Colebrook, 2006).

\section{Sensing the other: Body care and alterity}

So far, I have decentered the discourses and norms of beauty and body care through the lens of the intersecting axes of gender, race, and class difference by also introducing the specificity of the postcolonial Brazilian context. I broadened the discussion by illustrating the ambivalent notion of sensing beauty and the normalizing but also destabilizing effects attached to it, especially in the context of Brazil's recent history of hygiene discourse and politics. The preceding excursion into the Brazilian context will help retrace my interlocutors' thoughts and perceptions more easily. In this section, I focus on how body, corporeality, and embodiment construct otherness in transnational migration contexts and how Brazilian women approach body care to destabilize and alter discriminatory ascriptions.

The women who took part in my research are exemplary of the feminization of Brazilian migration in Germany, with women accounting for more than $73 \%$ of Brazilian migrants in the official statistics for the first decade of the 2000s (AZR, 1990-2000). At the time of my research, their ages ranged from 25 to 53 years. The majority had arrived in Germany in the mid-1990s and early 2000s from all over Brazil, and many of them had married a German man. They had mostly grown up in lower-middle class families and referred to their skin color as other than white. After deciding to stay and live in Germany, their labor market access was highly restricted due to the refusal to recognize the professional education and work experience they had gained in Brazil before their migration. They also faced diverse forms of racism, including being classified as Ausländer (foreigner) when looking for a job and suffering other forms of vocational devaluation. Like many other Brazilians in Germany and elsewhere, they-almost without exception-started earning money in ethnicized and feminized fields of work before entering the waxing business. However, they quickly realized that-in contrast to being classified as Ausländer-to be recognized as Brazilian provided them with rather positive reactions that not least influenced their opportunities on the job market. The intersection of their gender, skin color, and nationality ascribed to them stereotypical attributions of Brazilianness, which then imputed to them a naturalized vocation for certain work segments, especially in the care sector (see Lidola, 2015). Hence, while the Brazilian migration represents a greater-than-average feminization in Germany, women's entrance into the labor market shows parallels to other Brazilian migration contexts, especially in Southern Europe, where an intersecting racialization and sexualization constructed them as exotic other (e.g. Piscitelli, 2008; Padilla, 2006). Their supposed Brazilianness, in turn, distinguished them from other people classified as Ausländer in Germany and would also become a resource.

Brazilian migrants experienced everyday racism and stereotyping not only in the job market and in work contexts. Their interpellation as "other women," "foreigners," or "Brazilian women" pervaded their everyday lives in Germany in manifold situations. Their non-white skin and class status already manifested as colonial difference on their bodies in Brazil, where most of my interlocutors told me of their personal struggles, structural disadvantages, and experiences of racism before migration. However, they also told me about their personal tactics of body care and beauty practices to maintain conformity with normative body images in order to manipulate their social positioning in Brazil. In Germany, these women experienced their embodied difference in a much more rigid way. While they continued manufacturing their bodies via routinized and naturalized everyday body and beauty practices that performed the discursive norms and social meaning of their socialization context in Brazil, they had to realize that these norms and meanings were different in Germany. Now, they embodied the still-powerful colonial difference in two ways: Unlike in Brazil, where as non-whites they were part of the nation despite (post)colonial differences and were able to manipulate their social location in terms of race and class belonging to a certain extent through their bodies and body practices, as migrant women in Germany they embodied a non-belonging that seemed impossible to manipulate and which also denied them any possibility of passing. This seemingly non-manipulable materiality of an embodied unbelonging was not only discursively and 
physically experienced by these women through repeated practices of exclusion and devaluation; it was also emotionally experienced and manifested as pain, anger, fear, and sadness.

However, the emotionally felt materiality of an embodied difference also altered and sharpened my interlocutors' ways of perceiving German otherness, in turn: General observations considered first of all a common narrative that was still dominant in the late 1990s and early 2000s that Germans lacked personal hygiene, as they appeared to be not "very fond of bathing." This narrative was fueled by sensing unfamiliar odors in public places and on public transportation, which especially in the cold season were identified as a "mixture of fusty moisture, cold sweat, and other sickly body liquids" (statement made by Eliane, a then-36-year-old trained teacher from Bahia who worked for years as a nursemaid in Berlin). The narrative of lacking hygiene was also translated into the living environment, namely the streets and public parks of Berlin: "It was all full of dog poop, everywhere was poop! You had to constantly mind your step!" Eliane continued, referring to her disappointment when I asked her to recall her impressions of her first months after her arrival in Berlin. Thus, she reflected her experiences of being rejected as "other", as Ausländer and projected her feelings onto her new living environment, which she then perceived as repellent.

My interlocutors' narratives about affective experiences and perceptions of otherness were especially extensive and intense with regard to German women, whose differing corporeality was constantly compared to the culturally coded ideas and norms of femininity into which my interlocutors had been socialized in Brazil. They observed this difference in the other women's movements, gestures, postures, and clothing and in their own appropriately groomed bodies. "German women seemed so hard [durão], they were so stiff," commented Carminha, who was born in 1960, in one of our conversations. She contrasted this with her own body movements and corporeality as soft [suave]. "They almost didn't dare to look pretty, to decorate themselves or to show their bodies," criticized the 33-year-old Neide ${ }^{* 4}$ when asked about her impressions of her first months in Germany in the early 2000s. While their body care and beauty practices had especially focused on the dissimulation of a racialized and class-ified body in Brazil, Brazilian women discovered the accentuation of gender and the pronounced differentiation in the definition of femininity, made intelligible and meaningful as a capitalizable resource. This became especially important because German women-due to their intersecting race, class, and nationality-were perceived as in a comparatively closer, advantaged social position to the white ideal with which these women had been socialized in Brazil and which became even more inaccessible in Germany.

However, the still-powerful equation of "white" with "modern" that was so dominant in Brazil changed for these women in Germany. In Brazil, as shown above, being modern overlapped with the (gendered) idea of hygiene and cleanliness, especially with regard to one's own corporeality. In stark contrast, Silvana-born in 1972 and now the head of a franchise group of five waxing studios-said that Germans had long seemed "scruffy" to her. She and other women came to this conclusion on the basis of olfactory and visual perceptions. These included the smell of sweat or the lack of smell of perfume, deodorant, creams, or shampoo and conditioner, as well as skin and hair that was too dry, too oily, or generally "unclean"-all superficial characteristics that could easily be counteracted with appropriate personal hygiene and toiletries. It was precisely this pronounced sense of body care which had been so strongly communicated to women in Brazil that was now perceived as insufficient or even missing among German women. ${ }^{5}$

Yet most of all, it was the (visible) presence of body hair-common in Germany until the early 2000s - that motivated such a judgement. While my interlocutors considered Germans to have a "natural" beauty (here closely tied to a white ideal), this was impaired by a feral and untended-that is, hairy-body, which is why they primarily had ascribed a lacking femininity to German women. For instance, Carminha said that German women seemed to her "quite barbaric" (meio bárbaro). Especially with regard to body hair, a narrative of alterity developed which not only referred to differing gender norms and corporeality but encompassed a culturalized dimension. Statements like

\footnotetext{
4 Only the names marked by * indicate pseudonyms.

5 Statements like this were always shifted into the past, usually as an experience shortly after arrival in Berlin. Overall, however, a change in the perception of body care among German women in recent years can be observed, which my interlocutors ascribed to body care practices and body images popularized in the media.
} 
Carminha's about the naturalized presence of body hair in German women as barbaric; comparisons to animals ("She looked like a bear down there," Frances-Clai) or flora ("jungle," "bush," "Amazonian forest"); or indirect temporal classifications ("The cave times are over!", Ana*) referred to a cultural deficit among Germans in the eyes of Brazilian women. These evaluations were expressed with an affective reaction of disgust. Fifty-year-old Frances-Clai, who was one of the first Brazilian women in the waxing business in Berlin, re-enacted a visit to a hairdresser's where the hairdresser had pronounced armpit hair: "Oohh, I was so uncomfortable. I felt so sick. I almost threw up". She said that she even had to cut short her visit to the hairdresser's for this reason. Disgust "as an intense bodily feeling of being sickened" (Ahmed, 2004:85) is not a mere physicalpsychological reaction to something which is "naturally" repulsive. The expression and transmission of disgust and other affects, according to Gutiérrez Rodríguez, "occur in a space marked by historically produced, socially configured and culturally located power relations" (Gutiérrez Rodríguez, 2010:132). Such expressions carry with them the remains of the meaning of past experiences and are adjusted to the present.

The disgusted affective reaction to body hair can therefore and first of all be understood against the background of these women's experiences of socialization. As already mentioned, in Brazil, body hair was associated with dirt and impurity and considered repulsive from a sociocultural perspective. Now, body hair was even bound to a culturally coded alterity that my interlocutors evoked through constant comparisons, as Frances-Clai did: "In Brazil, there is nothing like that. You would never see something like that there." However, I would suggest an additional interpretation: I understand these reactions also as a symbolic inversion of the affective experiences of discrimination, racism, and unbelonging they have suffered as Ausländer on a daily basis since living in Germany. In their narratives about the alterity of the German "others," Brazilian women invert their positionality as objects of rejection and transform themselves into subjects of action and appreciation. That is, their evaluations and ascriptions of others as culturally deficient also implied a revaluation of themselves, precisely through referring to and performing a culturalized corporeality which actually also marked their colonial difference. For many of these women, body and corporeality already represented a compensatory resource in Brazil, even if under different sociocultural conditions, social-racial hierarchies, and regimes of meaning. In the German context, however, their bodies and corporeality reached beyond a symbolic and affective level of alterity and were emphasized as a strategic positioning necessity.

This strategic positioning was especially relevant for women whose work trajectories after migration were characterized by activities that affected their bodies and states of mind. Such occupations often included cleaning work, whether for private households or large companies. They used personal hygiene to compensate for broken fingernails, skin dried out by chemical detergents, sweaty hair, and other marked bodily consequences of their labor, as bodies begrimed and flawed by hard work had to be cleaned and repaired. In addition, the caring attention paid to one's own body was also perceived as a pleasant physical and mental recovery after the physical strain of hard work. A groomed body and mind furthermore concealed women's allocation in these precarious work fields. Some of my interlocutors pointed to a felt exigency especially with regard to the friends and family members of their German spouses. Retouching and masking one's marked body relativized the social stigmatization associated with these jobs and opened up the possibility of social mobility, while a deficient physical appearance, in contrast, was judged as contributing even more to a felt inferiority. More than this, caring for one's body was also an act of restoring femininity, given that a body physically marked by hard work was perceived not just as a marker of class but also of masculinity in both the Brazilian and the German context. And femininity, in turn, was an important feature for the interpellation as "Brazilian woman", in contrast to the Ausländer.

Furthermore, the few feminized work fields accessible to most Brazilian migrants in the first months after their arrival in Germany also required a feminized body. A groomed body was considered an indicator for caring competences when looking for a job. Ana, ${ }^{*}$ who was born in 1978 and became one of the first owners of a waxing studio in 2006, told me that a well-groomed body served as a point of reference for her expected dedication to the persons whom she would be assigned to care for. A well-groomed appearance was also required and differential for women who 
had previously worked in other roles involving emotional labor-for example, as waitresses or receptionists. In these areas, the women were expected to embody the stereotype of the "Brazilian"-if not in a sexualized way, then at least through a beautiful, well-groomed, and (therefore) feminine appearance. Hence, aware of the sexualized, exoticizing stereotype of the "Brazilian woman", these women actively sought a differentiation of their performance of emotional labor in contrast to rather sexualized practices. The strong demarcation was especially important in intimate labor settings in order to not confound their form of service with erotic intentions in the eye of the client (Lidola, 2013). This boundary work became even more important in the waxing business, as I will show below.

Last but not least, these observations must also be read against the context in which my research took place. Just as a well-groomed appearance was understood as an indication of women's competence in fields of care work and emotional labor, it influenced the business success of waxing and the judgement of these women's work performance as depiladoras. Ana* told me: "My body is already an advertisement." Neide* said: "I have to be a role model, because otherwise the customers will ask why I want to sell them a treatment." Even though their bodies and corporeality deviated from the white ideal of social belonging in Germany and of the international beauty industry, they were the main instruments of their advertisement and work performance.

In all these examples, body and corporeality became an invaluable resource for successful integration into one of the few fields of work accessible to Brazilian working class women in Germany. Yet while my interlocutors identified class and race positionalities as the most relevant to address and manipulate via body care and beauty practices in order to minimize discrimination and social devaluation in Brazil, gender (in its intersectionalities) —or, more precisely, a culturally coded and socially normed femininity - became the center of their attention in Germany. Thus, unlike the race and class ascriptions they had faced as migrants and foreigners in Germany, gender became malleable and allowed for agency in the transnational context. However, these women were also confronted with the stereotype of the "Brazilian woman", which contained the imaginary of a careful, sensitive, however also eroticized and exoticized femininity. Brazilian migrants balanced their positionality by nuancing the caring side rather than the sexualized attributions when performing Brazilianness in order to destabilize the stereotype.

\section{Teaching femininity and making humans: Civilizing the other's body}

Entering the waxing business in the second half of the 2000s, my interlocutors had to face the initially outlined polarizing and polemicizing controversy about body image and gender norms tied to depilation. This was further complicated by their positionality as migrants in German society, especially in the labor market. They had to overcome their status as embodied Ausländer in intimate service work (Boris; Parreñas, 2010) in which those performing and those receiving the service encounter each other in the most intimate way and where the touching of the other's body occurs in its most sensitive areas. At the same time, these women still had to persuade their potential clients to purchase this service, for neither the waxing technique nor the intended result of a hairless body was widespread in the early years of the studios and were certainly not known as a commercialized service. Their work even encompassed much more than just body work, but also work on femininity that implied emotional and cultural work on notions of alterity, care, and humanity. Building on the previous discussion on how intersecting dominant regimes of differences might become challenged through shifting meanings regarding gender in transnational contexts of encounters and imaginaries, I now add the peculiarity of intimate caring relations. In the following I will show that, similar to findings in other forms of transactions of money and affect, the intimacy of affective encounters in the waxing cabin holds the potential of blurring boundaries of social positionalities and opens the possibility of agency (cf. Piscitelli, 2016). But first, I start with a closer look at the ambivalent meanings of body hair.

Waxing's special place in the spectrum of beauty and body care practices might be derived from the special symbolic nature of hair. Hair in general is characterized by an ambiguity that refers back to its nature: On the one hand, it is often categorized as "dead matter" and comes from "a domain associated with [...] impurity" (Haas, 2008:16), but on the other, it is an "expression of the 
vitality of the human being" (Haas, 2008:18). Hair is simultaneously considered a "natural sign" and a "cultural sign" (Haas, 2008:18). Viewed only from the angle of gender and sexuality, body hair has long been associated with (sexual) maturity and masculine strength (Cooper, 1971), especially in Western cultures of the $20^{\text {th }}$ century. In accordance with some structuralist sociocultural approaches, allowing body hair on men might be understood as the male-coded ability to dominate the danger emanating from that which is natural, wild, and uncontrolled (Ortner, 1974). Meanwhile, feminist activists and scholars have argued that the hairless norm for women signals that their "bodies are not attractive or indeed acceptable when natural" and even perceived as dangerous, for which reason they must be tamed (Basow, 1991:86). Women must therefore both "make [...] the effort to be hairless and make the state of hairlessness appear "natural" (Toerien; Wilkinson, 2003:339). The requirement for women to remove their body hair may thus "reflect the sociocultural equation of femininity with a child-like status, passivity and a dependence on men" (Toerien; Wilkinson, 2003; Basow; Braman, 1998). Within this line of argument, body hair, especially intimate hair, became the "last frontier" in the battles against the expansion of beauty imperatives (Hildebrandt, 2003), where depilation is considered the epitome of the infantilization of women and their submission to patriarchal fantasies and control (Peixoto Labre, 2002). In this sense, women are said to be urged to construct the merging of femininity, nature, and their corporeality through permanent cultural work on their bodies to demarcate it from a "natural" (i.e., hairy) condition in order to become "naturally" feminine.

With the entry of waxing into the German beauty service sector, it was therefore not just the hairy body at which mostly Brazilian depiladoras initially aimed their efforts. My interlocutors stated that their service first tended to work on making their German clients' bodies feminine, as they had perceived a lack of it in everyday encounters. Rather than their positionality as Ausländer, it was their interpellation through the stereotype of the "Brazilian woman" that assigned them the status of experts in this field. However, instead of resorting to the domain of representation, they sought the sensuous and affective dimension of beauty and well-being. The women resorted to the feel-good narrative which was already so powerful in Brazil and which they, in the first instance, decoupled from body hair removal. They emphasized their own socialization in Brazil-for example, when Silvana R., who during a three-month vacation in Brazil trained to become a depiladora, said: "We Brazilians are very beauty-conscious. I think that's good. Maybe the Germans should learn it, this feeling of well-being. And how does a woman feel good? If the hair is in place and has a nice cut, if the skin is smooth and beautiful - at least that's how a woman feels comfortable in Brazil. That's why it is seen here that Brazilians are beautiful women. But they do something to make them beautiful." Being pretty and feeling good are considered complementary in this and other statements.

Far from being something given, beauty was perceived to be created through one's own efforts. It is precisely through this that my interlocutors relativized stereotypical ideas about the "Brazilian woman" by reinforcing their efforts and body work, as in a statement from Marta*:

The Brazilian woman is beautiful [...]. The hair is beautiful; the nails are done. She just takes care of these things. She can be fat or thin, but she takes care of these things. That's why the image of Brazil is so closely tied to the image of a beautiful woman. So not in a derogatory way, but more like this: 'I want to be as beautiful as a Brazilian woman, I want to look so wellgroomed,' right? I think that idea sells very well.

Through the nuanced embodiment of the Brazilian stereotype of a beautiful woman-as Marta* born in 1965, addresses it with the reference "not in a derogatory way"-Brazilian women not only serve as role models but are considered to be legitimized professionals to pass on the feeling of wellbeing sought through body care, as shown in the introductory remarks. This is especially compelling because Brazilian migrants had hardly worked in the beauty sector before the introduction of waxing as a cosmetic service in Germany. The nuanced appropriation of stereotypical elements thus reinforced ascriptions of being specialists not only in Brazilian waxing but also in beauty and beauty practices in a broader sense. According to my interlocutors, this included (in addition to a hairless body) well-groomed, smooth, fragrant skin and hair; clean nails; and a freshened and healthy 
appearance-physical dimensions which could be perceived by their clients not only visually but also olfactorily and haptically and which symbolized an embodied modernity. Yet this nuanced, performative reference to the (stereotypical) idea of the "Brazilian woman" via corporeality, appearance, and behavior towards the customer also meant a balancing act: It was necessary to show a well-groomed, attractive body, but not to create the impression of an alleged (hyper)sexuality also anchored in the stereotype of the "Brazilian woman." It meant to embody a caring femininity that is inscribed into the history of colonized female alterity, and to simultaneously deny the interpellation of a sexualized otherness inherent to colonial desire. It meant to perform a domesticated, that is hygienic, body, which is at the same time not the object of a violent act of invasion (cf. McClintock, 1995), but a sensing agent of a caring subjectivity.

Conscious about the impression that her embodied presence and behavior left on other women, Carminha said: "My customers are observing me. How I behave, how I walk, all very feminine. I think they like that. They appreciate it and even learn from me". She and others saw their service performances also as educational work in personal hygiene and femininity, not only indirectly but often straightforwardly. They motivated their clients (sometimes in a more joking and tender way) to make their bodies more feminine, as Angelica told me: "I always tell them: "Watch your nails, take care of your hair' and things like that. 'It's not just for beauty. It's for your personal hygiene and wellbeing. You give yourself a gift. [...] As a woman. And not as a hairy little animal [bixinho cabeludo]"'

In doing so, depiladoras also placed femininity in direct relation to the current controversy about a backlash due to the new waxing boom. Frances-Clai, for example, pointed out:

There are women who do it for a man. But we, for example, don't have our thoughts like that. I do it for me. Because I feel comfortable doing it. And because it's hygienic. I'm single now. But that means I still don't want a jungle just because I'm single. No! I'm doing it because I don't want the hair here. It makes me feel clean. And yet I'm an emancipated woman, aren't I? Am I?! And that has nothing to do with my hair down there!

In this statement, Frances-Clai decoupled the discourse about emancipation from body hair removal and assigned them two different domains of meaning. She thus opposed dominant Western feminist positions, which propose a close connection between the two. At the same time, she included herself in the argument as proof of this decoupling: She-the hardworking business woman, single mother and well-known personality within the Brazilian migration community-embodies emancipation, even though she was repeatedly confronted with disadvantages and discrimination in the course of her migration trajectory. Accordingly, she pointed out: "Emancipated is a woman who goes her own way and does her own thing. But this has nothing to do with personal hygiene or the lack of it". Then she immediately corrected herself: "But that is also wrongly said. Hey, if she likes her hair, then she likes it. Emancipated is a woman who knows for herself, independent of anyone. But that has nothing to do with hair here or there [pointing to her vagina and armpits]. And that's what we explain to our clients". By emphasizing emancipation, Frances-Clai and other waxing studio owners claimed to take part in modernity by complying with the image of a modern woman who is selfdetermined and independent.

Yet, Brazilian women also related their understanding of being modern to notions of hygiene and cleanliness. This was manifest in their perceptions and practices of personal hygiene and body care but became even clearer in their waxing studios. While waiting rooms, like the studios' names, presented stereotypical images of Brazil (beaches, tropical flora and fauna, the colors of the Brazilian flag, and so on), the treatment cabins were characterized by their sterility. They were light and clear, with furnishings reduced to the bare essentials and the treatment cot often medical equipment. My interlocutor told me that they had forced this medicalizing atmosphere in their cabins to enhance their professional performance, as they were approaching their clients' most intimate body parts, which normally only medical professionals-who are considered at least as equals to their clients in terms of (racialized) class belonging - can access in times of physical need.

Presenting their culturally branded studios as clear and modern also represented a demarcation from my interlocutors' preconceptions of other migrant communities' "ethnic" 
businesses as folkloric, kitschy, and therefore backward. At the time of my research, a high number of beauty salons especially in Muslim migrant neighborhoods in Berlin offered depilation among other services. But their main clientele was composed of migrant, and not German, women. In interviews, Turkish and Lebanese salon owners blamed persistent orientalist prejudices against "Arab" or Muslim women that connect them to an un-emancipated and therefore backwardoriented femininity that stands in contrast to a modern understanding of womanhood. This imaginary was extended to a seclusive corporeality and restricted sexuality. Younger beauticians also lamented that the first migrant generations would have directed their advertisement to a coethnic clientele and therefor nurturing already existing preconceptions of "ethnic" businesses as segregated spaces. In our conversations, Brazilian depiladoras echoed these observations of stereotypical ascriptions especially regarding an orientalist femininity as incompatible to an idea of Western-that is modern-femininity. In contrast, Brazilians addressed right from the very start primarily a non-migrant/German clientele of a more affluent class for their service: waxing studios are in their majority located in better-off neighborhoods with a lesser migrant composition, and they advertise their service by using familiar images of the beauty industry that mainly show white female body parts. Hence, they refer to a modern body as an ethnically unmarked body, represented in a branding that might be Brazilian, but only in terms of its stereotypical borrowings of Brazilianness that are compatible with the idea of a modern, unrestricted, yet non-erotic corporality.

However, my interlocutors also presented another reading of their efforts to be modern. Various terms such as "jungle," "bush," "bear," "little animal," "barbarian," and the many other metaphors and comparisons that I heard during my research on body hair pointed to a further dimension that these women associated with their service, namely culturalizing the body. One client, Franziska, who described herself as one of the first regular waxing clients in Germany, told me: "My nickname is 'macaquinha,' meaning little monkey. Because, before my first treatment, I had such a stark moustache. After the treatment Laura ['her' depiladora] said to me: 'So, now we have made a human being out of you again"'. Carminha made this concern even clearer: "We have to educate them [the Germans] properly, what hygiene is, what a well-groomed body is. This is a mission of civilization". Here, the hairless body is not an infantile, sexually repressed, pornographic, and socially exposed body. On the contrary, it is a well-groomed, hygienic, and therefore cultivated and civilized body which characterizes the modern woman and is at the same time a duty to oneself. Depilation becomes a culturalizing care work which produces and maintains a healthy and civilized body. "Making people" out of clients was often accompanied by advice on other body care practices that would make the skin softer, the hair shinier, the teeth whiter, or even the movements softer: a cultivation of the body and corporeality through de-naturalization.

This cultural work did not only imply work on bodily appearance but also on perceptions of alterity and sociality: Despite their alleged conformity to the racialized logic of colonial difference in Western modernity, European bodies were also imperfect and needed permanent body work, too. My interlocutors considered their body labor as more than just restoring or manufacturing human bodies but also as repairing Germans' sociality with the "other", the Ausländer, the migrant woman-that is, restoring the Germans' humanity. Brazilian depiladoras therefore reversed the notion of care: Educating their clients to care about themselves first of all implies the need to recognize oneself as a sensitive and sensing being (thus countering the perceived rigidity of Germans). Second, touching and grooming the other's body addresses the other's emotional need to be cared for-for my interlocutors, a fundamental characteristic of being human. Third, for the Germans to allow themselves to be touched, to let their bodies become culturally modeled by the hands of others, was regarded as the antipode of racism and discrimination by my interlocutors, constituting a sociality of with-ness.

My interlocutors' statements about civilizing the other woman's body is therefore, as I read it, a reversal of the Western colonial discourse of modernity with which these women were acquainted in Brazil and which had found its way into the most intimate corners of private life. While in Western colonial discourse, it was the "barbaric" and thus racially and culturally inferiorized "other" who had to be tamed and civilized, my interlocutors inverted the civilizing mission. The object of cultural work was now the European "other" who had for so long embodied the ideal of modernity. The mission 
was also not a masculine and violent act of invasion of a feminized wilderness in order to dominate the other's body (cf. McClintock 1995), and where hygiene served as an instrument to establish a regime of difference among people. Brazilian migrants saw their mission rather in a domestication and transformation of the masculinized other through an act of care, where hygiene rather blurred regimes of differences, and where their (body) care restored a shared humanness among themthe non-white, feminine subaltern, and their white German clients.

Summarizing and comparable to other caring and intimate labor settings (cf. Piscitelli, 2016), it can be said that in the intimacy of the affective encounter within the waxing cabins, notions of alterity and otherness were not defined in terms of rigid categories like race, class, nationality, and the like but by malleable ascriptions of culturalized versus uncultured or even unhuman that were modifiable through the work of (body) care. These observations can be compared to other caring and intimate labor settings. However, my Brazilian interlocutors knew that their care was nothing abiding or stable but instead fragile, framed by intersecting power structures and in need of permanent repetition.

\section{Conclusion: Humanizing sociality}

The Brazilian depiladoras and waxing studio owners in Berlin have contributed to the establishment of a service that has long been unknown in Germany. Body hair removal by means of waxing was an opportunity to acquire a business sector that was already dominated by Brazilians in other countries, such as the United States. In the German context, Brazilian migrant women were able to occupy this business with beauty and body care narratives that consider the perceptions and definitions of beauty into which they were socialized in Brazil but which were also affected by their experiences of German alterity after migration and furthermore drew on (internationally established) stereotypical ideas about the "Brazilian woman". Upon entering the waxing business, these women were able to perform as professionals and experts on beauty matters and body care, which provided them with an agency that they had hardly experienced when working in other feminized and ethnicized labor market segments in Germany. They gained visibility as successful workers and business women, which eventually translated into social recognition in their everyday lives.

Waxing studios also function as places of encounters and exchange between women who rarely come together in such intimacy. Through being categorized as the "other", as Ausländer, and as migrants, my interlocutors have been repeatedly made aware of their alleged deficits in other work contexts and everyday situations, where they have barely been granted advisory or even educational positions. However, in the waxing cabins, they not only shaped their clients' bodies but educated them on personal hygiene and wellbeing. In doing so, they positioned themselves against Western feminist discourses, which conceived body hair as "the last frontier" in the battle against beauty imperatives (Hildebrandt, 2003). They countered the discourse on beauty and women's oppression by introducing a discourse on hygiene that was not one of violent domestication, but of care and humanization. Depiladoras stated that they manufactured-or even "civilized"-the uncultured, "unfeminine," and "unhuman" corporeality of their German clients into culturalized, hygienic, feminine, and (not least) humanized beings: narrative figures with whom they were acquainted as part of the (post)colonial discourse of alterity and beauty in Brazil. Their humanizing work did not end in their clients' bodies but also encompassed sociality: Addressing the sensuous and emotional dimension through touching and caring for the other's body, my interlocutors created a being together in with-ness that transcended for the moment social hierarchies of difference. The sensuous and sensitive dimension of beauty and related body work provided an affective, caring relation between Brazilian depiladoras and their predominantly German clients that is incommensurable with the logics of discourse but exceeds them (Jarrín, 2017; Villa, 2010). Thus, beauty work as a form of care and intimate labor holds the potential to trouble, queer, or even destabilize social and racialized hierarchies and discursive norms as it opens up counter-hegemonic agency (Jarrín, 2017; Edmonds, 2010; cf. Piscitelli, 2016). This caring relation even enabled the performativity of a more humanized sociality.

Ultimately, I want to point to the potential of taking the emotional and sensitive dimension of my interlocutors as the basis for mutual knowledge production: It offers the possibility to "look back" 
to the majority society and dominant culture by applying the very same means, norms, and discourses to which the "other" has normally been subjected, but adopting them to the domain of care. I am aware that my focus is partial and blends out the coloniality of feminized labor and of the beauty norms of which the waxing business is a part, and I am aware of the situatedness and fragility of my interlocutors' interpretations. However, to strengthen and consolidate their views also demands permanent effort-a characteristic shared with their body work. This may even allow to think of body care from a rather decolonial perspective - a perspective, which de-hierarchizes caring relations and sociality.

\section{References}

ADELMAN, Miriam; RUGGI, Lennita. Corpo, identidade e a política da beleza: algumas reflexões teóricas. In: BERETA DA SILVA, Cristiani; ASSIS, Gláucia de Oliveira; CÁSSIA KAMITA, Rosana (org.) Gênero em movimento: novos olhares, muitos lugares. Ilha de Santa Catarina, Editora Mulheres, 2007, pp.277-292.

AHMED, Sara. The cultural politics of emotion. New York, Routledge, 2004.

AHMED, Sara. Strange encounters: embodied others in post-coloniality. New York, Routledge, 2000.

ANDRADE, Sandra dos Santos. Saúde e beleza do corpo feminino: algumas representações no Brasil do Século XX. Movimento (9), Porto Alegre, Escola de Educação Física, Fisioterapia e Dança/UFRGS, 2003, pp.119-143.

AZR, 1990-2000. Ausländische [https://wwwgenesis.destatis.de/genesis/online/link/tabellen/12521*, acesso em: 14 maio 2016].

BASOW, Susan A. The hairless ideal: Women and their body hair. Psychology of Women Quarterly, 15(1), 1991, pp.83-96.

BASOW, Susan A.; BRAMAN, Amie C. Women and body hair. Psychology of Women Quarterly, 22(4), 1998, pp.637-645.

BORIS, Eileen; PARREÑAS, Rhacel Salazar. Introduction. In: BORIS, Eileen; PARREÑAS, Rhacel Salazar (org.). Intimate labors: cultures, technologies, and the politics of care. Stanford, Stanford Social Sciences, 2010, pp.3-17.

BORKENHAGEN, Ada; BRÄHLER, Elmar. Die nackte Scham - Theoretische und empirische Aspekte des aktuellen Trends zur weiblichen Teil- bzw. Vollintimrasur. In: BORKENHAGEN, Ada; BRÄHLER, Elmar (org.) Intimmodifikationen: Spielarten und ihre psychosozialen Bedeutungen. Gießen, Psychosozial-Verlag, 2010, pp.7-12.

BRAND, Peggy Z. Beauty Matters. Bloomington, Indiana University Press, 2000.

BUTLER, Judith. Bodies that matter: on the discursive limits of "sex". New York, Routledge, 1993.

COKAL, Susan. Clean porn: the visual aesthetics of hygiene, hot sex, and hair removal. In: HALL, Ann C.; BISHOP, Mardia J. (org.). Pop-porn: Pornography in American culture. Westport, Praeger, 2007, pp.137154.

COLEBROOK, Claire. Introduction: special issue on beauty and feminist theory. Feminist Theory, 7(2), 2006, pp.131-142.

COOPER, Wendy. Hair: sex, society, symbolism. London, Aldus, 1971.

CRAIG, Maxine. Ain't I a beauty queen? Black women, beauty, and the politics of race. Oxford, Oxford University Press, 2002.

DAVIS, Dána-Ain; CRAVEN, Christa. Feminist ethnography: thinking through methodologies, challenges, and possibilities. Lanham, MD, Rowman \& Littlefield, 2016.

DEL PRIORE, Mary. Corpo a corpo com a mulher: Pequena história das transformações do corpo feminino no Brasil. São Paulo, Editora SENAC São Paulo, 2000.

EDMONDS, Alexander. Pretty modern: Beauty, sex, and plastic surgery in Brazil. Durham, Duke University Press, 2010. 
EDMONDS, Alexander. 'Triumphant miscegenation': Reflections on beauty and race in Brazil. Journal of Intercultural Studies, 28(1), 2007, pp.83-97.

FREYRE, Gilberto. Modos de homem \& modas de mulher. Rio de Janeiro, Editora Record, 1987.

GOLDENBERG, Mirian. The body as capital: Understanding Brazilian culture. Vibrant - Virtual Brazilian Anthropology, (1), Brasília, Brazilian Anthropology Association, 2010, pp.220-238.

GUTIÉRREZ-RODRÍGUEZ, Encarnación. Migration, domestic work and affect: a decolonial approach on value and the feminization of labour. New York;London, Routledge, 2010.

HAAS, Birgit (org.). Haare zwischen Fiktion und Realität: Interdisziplinäre Untersuchungen zur Wahrnehmung der Haare. Berlin/Münster, Lit-Verlag, 2008.

HILDEBRANDT, Sarah. The last frontier: body norms and hair removal practices in contemporary American culture. In: TSCHACHLER, Heinz; DRAXLBAUER, Michael (org.). The EmBodyment of American Culture. Münster, Lit-Verlag, 2003, pp.59-71.

JARRÍN, Alvaro. The biopolitics of beauty: cosmetic citizenship and affective capital in Brazil. Oakland, CA, University of California Press, 2017.

KANG, Miliann. The managed hand: Race, gender, and the body in beauty service work. Berkeley, University of California Press, 2010.

LIDOLA, Maria. Of grooming bodies and caring souls: New old forms of care work in Berlin`s Brazilian Waxing Studios. In: ALBER, Erdmute; DROTBOHM, Heike (org.). Anthropological Perspectives on Care. Work, Kinship and the Life-Course, Basingstoke, Palgrave Macmillan, 2015, pp. 69-90.

LIDOLA, Maria. Changing boundaries and redefining relations: Migration and work experiences of Brazilian women in Germany. FIAR Forum for Inter-American Research. The Journal of the International Association of Inter-American Research (IAS), 6(2), 2013, interamericaonline.org/volume-6-2/lidola/.

LIEBELT, Claudia. Manufacturing beauty, grooming selves: the creation of femininities in the global economy-an introduction. Sociologus, 66(1), 2016, pp.9-24.

McCLINTOCK, Anne. Imperial leather: race, gender and sexuality in the colonial contest. New York, Routledge, 1995.

MACHADO-BORGES, Thaïs. Producing beauty in Brazil: Vanity, visibility and social inequality. Vibrant Virtual Brazilian Anthropology, 6(1), Brazilian Anthropology Association, 2009, pp.208-237.

NASCIMENTO, Elisa Larkin. The sorcery of color: Identity, race, and gender in Brazil. Philadelphia, Temple University Press, 2007.

ORTNER, Sherry B. Is female to male as nature is to culture? In: ROSALDO, Michelle Zimbalist (org.). Woman, culture, and society. Stanford, Stanford University Press, 1974, pp.68-87.

PISCITELLI, Adriana. Economias sexuais, amor e tráfico de pessoas: novas questões conceituais. cadernos pagu (47), Campinas, SP, Núcleo de Estudos de Gênero-Pagu/Unicamp, 2016. pp.132-162.

PISCITELLI, Adriana. Looking for new worlds: Brazilian women as international migrants. Signs, 33(4), 2008, pp.784-793.

PADILLA, Beatriz. Integração dos "imigrantes brasileiros recém-chegados" na sociedade portuguesa: problemas e possibilidades. In: MACHADO, Igor José de Reno (org.). Um mar de identidades: a imigração brasileira em Portugal. São Carlos Edufscar, 2006, pp.19-42.

PEIXOTO LABRE, Megdala. The Brazilian Wax: New hairlessness norm for women? Journal of Communication Inquiry, 26(2), 2002, pp.113-132.

SANT'ANNA, Denise Bernuzzi de. Higiene e higienismo entre o Império e a República. In: DEL PRIORE, Mary; AMANTINO, Marci. (org.). História do corpo no Brasil. São Paulo, Editora Unesp, 2011, pp.283312.

SANT'ANNA, Denise Bernuzzi de. Horizontes do corpo. In: BUENO, Maria Lúcia; CASTRO, Ana Lúcia. (org.). Corpo, território da cultura. São Paulo, Annablume, 2005, pp.119-134. 
SANT'ANNA, Denise Bernuzzi de. Cuidados de si e embelezamento feminino: Fragmentos para uma história do corpo no Brasil. In: SANT'ANNA, Denise Bernuzzi de (org.). Políticas do corpo. São Paulo, Estação Liberdade, 1995, pp.121-139.

SKEGGS, Beverley. Formations of class and gender: Becoming respectable. London;Thousand Oaks, Sage Publications, 1997.

SUNANTA, Sirijit. Globalising the Thai "high-touch" industry: exports of care and body work and gendered mobilities to and from Thailand. Journal of Ethnic and Migration Studies, 46(8), 2020, pp.1543-1561.

TIGGEMANN, Marika; LEWIS, Christine. Attitudes towards women's body hair: Relationship with disgust sensitivity. Psychology of Women Quarterly, 28(4), 2004, pp.381-387.

TOERIEN, Merran; WILKINSON, Sue. Gender and body hair: Constructing the feminine woman. Women's Studies International Forum, 26(4), 2003, pp.333-344.

VARTABEDIAN, Julietta. Beauty that matters: Brazilian travesti sex workers feeling beautiful. Sociologus, 66(1), 2016, pp.73-96.

VILLA, Paula-Irene. Embodiment is always more: intersectionality, subjection and the body. In: LUTZ, Helma; HERRARA VIVAR, Maria Teresa; SUPIK, Linda (org.). Framing intersectionality: debates on a multifaceted concept in Gender Studies. Farnham, Ashgate, 2010, pp.171-185.

WOLF, Naomi. The beauty myth: How images of beauty are used against women. New York, W. Morrow, 1991.

ZELIZER, Viviana. The purchase of intimacy. Princeton, Princeton University Press, 2005. 